\title{
Tavuk gübresi uygulamalarının domates (Solanum lycopersicum L.) gelişimi ve verim üzerine etkilerinin belirlenmesi
}

\author{
Determination of the effects on tomato (Solanum lycopersicum L.) growth and yield \\ of poultry manure application
}

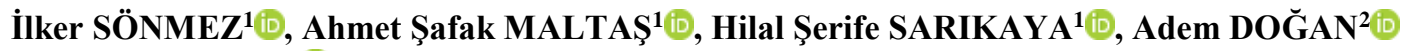 \\ Mustafa KAPLAN ${ }^{1}$ (iD \\ ${ }^{1}$ Akdeniz Üniversitesi Ziraat Fakültesi Toprak Bilimi ve Bitki Besleme Bölümü, 07058, Antalya \\ ${ }^{2}$ Akdeniz Üniversitesi Ziraat Fakültesi Bahçe Bitkileri Bölümü, 07058, Antalya \\ Sorumlu yazar (Corresponding author): İ. Sönmez, e-posta (e-mail): ilkersonmez@akdeniz.edu.tr \\ Yazar(lar) e-posta (Author e-mail): ahmetsafak@akdeniz.edu.tr, hilallsarikaya@gmail.com, ademdogan@akdeniz.edu.tr, mkaplan@akdeniz.edu.tr
}

\section{MAKALE BİLGISİ}

Alınış tarihi 11 Ekim 2018

Düzeltilme tarihi 14 Ocak 2019

Kabul tarihi 06 Mart 2019

\section{Anahtar Kelimeler:}

Tavuk gübresi

Domates (Solanum lycopersicum L.)

Organik gübre

Verim

\section{ÖZ}

Bu çalışma farklı tavuk gübresi dozlarının $\left(0 \mathrm{~kg} \mathrm{da}^{-1}, 600 \mathrm{~kg} \mathrm{da}^{-1}, 1200 \mathrm{~kg} \mathrm{da}^{-1}\right)$ domates (Solanum lycopersicon $c v$. Tayfun $F_{l}$ ) gelişimi ve verimi üzerine olan etkilerini belirlemek amacıyla sera koşullarında gerçekleştirilmiştir. Bu amaçla domates meyvesinde gelişme (meyve çapı, meyve ağırlığı, meyve sayısı, pH, asitlik, sertlik, SÇKM: Suda çözünebilir kuru madde, vitamin $\mathrm{C}$ ) ve verim değerleri ile bitki-meyve ve toprakta besin elementi konsantrasyonları (N, P, K, Ca, Mg, Fe, Zn, Mn, Cu) belirlenmiştir. Araştırma sonuçlarına göre domateste ortalama meyve ağırlığ 1 ve verim değerlerinde $600 \mathrm{~kg} \mathrm{da}^{-1}$ uygulaması en uygun doz olarak belirlenirken, meyve ve bitki besin elementi konsantrasyonlarında $1200 \mathrm{~kg} \mathrm{da}^{-1}$ uygulaması daha iyi sonuçların elde edilmesini sağlamıştır. Toprakların makro besin içeriklerinde $600 \mathrm{~kg} \mathrm{da}^{-1}$ uygulaması, mikro besin içeriklerinde ise $1200 \mathrm{~kg} \mathrm{da}^{-1}$ uygulaması en yüksek değerlerin elde edildiği uygulamalar olarak belirlenirken, en düşük değerler kontrol uygulamalarından elde edilmiştir. Tavuk gübresi uygulamalarının temel kimyasal gübrelerle birlikte uygulanmasının verim ve kalite parametrelerinde önemli katkılar sağladığı görülmüş olup, bu çalışmada düşük doz olan $600 \mathrm{~kg} \mathrm{da}^{-1}$ uygulamasının uzun süreli kullanımlarda toprak tuzluluğu problemi olușumunda risk olușturmayacağı ve ekonomik doz olarak değerlendirilebileceği düşünülmektedir.

\section{ARTICLE INFO}

Received 11 October 2018

Received in revised form 14 January 2019

Accepted 06 March 2019

\section{Keywords:}

Poultry manure

Tomato (Solanum lycopersicum L.)

Organic manure

Yield

\begin{abstract}
This study was conducted to investigate the effects of different poultry manure application $\left(0 \mathrm{~kg} \mathrm{da}^{-1}, 600 \mathrm{~kg} \mathrm{da}^{-1}, 1200 \mathrm{~kg} \mathrm{da}^{-1}\right)$ on growth and yield of tomatoes cultivation in greenhouse conditions. For this purpose, the values of growth (fruit diameter, fruit weight, number of fruit, $\mathrm{pH}$, acidity, fruit firmness, total soluble solids, vitamin $\mathrm{C}$ ), yield and the mineral concentrations of fruit-plant-soil (N, P, K, Ca, Mg, Fe, Zn, Mn, Cu) were determined. As a result of this study, the application of $1200 \mathrm{~kg} \mathrm{da}^{-1}$ at fruit and plant nutrient concentrations ensures better results while the average fruit weight and yield values are determined as the most suitable dosage for application of $600 \mathrm{~kg} \mathrm{da}^{-1}$. The application of $600 \mathrm{~kg} \mathrm{da}^{-1}$ at soil macro nutrient concentrations has the best value while the soil micro nutrient contents are determined as the most suitable dosage for application of $1200 \mathrm{~kg} \mathrm{da}^{-1}$ and the minimum values of mineral nutrient contents were obtained control application $\left(0 \mathrm{~kg} \mathrm{da}^{-1}\right)$. It has been observed that the chicken manure application with basic chemical fertilizers provides significant contributions in yield and quality parameters and it is considered that the dose of $600 \mathrm{~kg} \mathrm{da}^{-1}$ will not be a risk for soil salinization problem and can be evaluated as an economic dose over a long period of use.
\end{abstract}




\section{Giriş}

Topraklardaki verimlilik parametrelerinin geliştirilmesinde kimyasal gübrelemeye ilave olarak organik gübreleme büyük öneme sahip olup, bitkisel üretimdeki önemi ise gün geçtikçe daha da artmaktadır. Organik gübre kullanımı ile tarım topraklarında verimlilik artarken, toprak özelliklerinin iyileştirilmesi de toprakların sürdürülebilirliğinin sağlanmasında ve sağlıklı tarımsal ürünlerin elde edilmesinde anahtar rol oynamaktadır. Topraklara organik gübre uygulamalarıla toprakların fiziksel, kimyasal ve biyolojik özelliklerindeki değişimler toprakların gelecek nesillere daha üretken bir şekilde aktarılmasını sağlayacak yegâne uygulamalar olarak görülmektedir (Shirani ve ark. 2002; Bender ve ark. 1998; Tavalı ve ark. 2014). Organik gübreler içerisinde tavuk gübreleri önemli bir yer tutmaktadır. Gamliel ve ark. (1993) solarizasyon yapılan alanda kompostlanmış tavuk gübresi uygulamasının marul verimini önemli ölçüde $\operatorname{artırdığ~} 1$ belirlemiştir. Duyar (2007) tavuk gübresi uygulaması ile marul bitkisinde önemli oranda azot artışı sağlamıştır. Rynk (1992), diğer organik materyallere göre tavuk gübresi kompostunun toprak özellikleri üzerine iyileştirici etkisinin daha yüksek olduğunu bildirmiştir. Tavuk gübresi, solucan gübresi gibi üretim materyalleri tek başına bir organik gübre olmaktan ziyade, iyi bir toprak ıslah maddesi ve aynı zamanda kültür bitkilerini hastalıklara dirençli kılma özelliği olan çevreci ve ekonomik materyaller olup, bunların tarımsal amaçlı olarak kullanımı ülkemizde de giderek yaygınlaşmaktadır (Bellitürk 2016).

Kaplan ve ark. (2006), farklı organik gübre uygulamalarının marul yetiştiriciliğinde toprağın fiziksel ve kimyasal özellikleri üzerine etkilerini araştırmış, sıvı tavuk gübresi ve sıvı tavuk gübresinin kan unu ve katı tavuk gübresi ile kombinasyonlarının en iyi sonuçları veren organik gübre uygulamaları olduğunu belirlemiştir. Ogbadu ve ark. (1989), tavuk gübresinin patlıcanda ham lif, titre edilebilir asitlik miktarı ve toplam protein içeriğini önemli ölçüde artırdığını, hemiselüloz içeriğini ise önemli miktarda azalttığını belirlemişlerdir. Moreira ve ark. (2014), farklı organik uygulamaların (organik kompost, tavuk gübresi, sı ğır gübresi, koyun gübresi ve teker fasulye) marul bitkisinin verim ve gelişimine etkisinde en iyi sonucun tavuk gübresi uygulamasından elde edildiğini saptamıştır. Masarirambi ve ark. (2010), çeşitli seviyelerde tavuk gübresinin marulda gelişme, verim ve kalite üzerine etkilerini araştırmış, tavuk gübresinin 20,40 ve 60 ton ha ${ }^{-1}$ dozları uygulanmış ve en iyi verimin 60 ton ha ${ }^{-1}$ dozundan elde edildiği belirlenmiştir.

Artan dozlarda organik materyal uygulanan topraklarda yetiştirilen mısır bitkilerinin kuru madde miktarının ve $N, P$ ve $\mathrm{K}$ kapsamlarının artan oranlarda uygulanan organik materyaller ile arttığı saptanmıştır (Brohi ve ark. 1995). Kocabaş ve ark. (2007) tarafindan yapılan bir çalışmada, tavuk gübresi (TG), koyun gübresi (KG) ve sığır gübresi (SG) gibi çeşitli hayvansal gübreler ile bu gübrelerin kombinasyonlarının adaçayı bitkisinde etkilerinin araştırıldığı çalışmada organik gübre uygulamalarıyla, adaçayı bitkisinin uçucu yağ içeriği ve bitkinin $\mathrm{N}, \mathrm{P}, \mathrm{K}$ konsantrasyonları arasında pozitif yönde bir ilişki belirlenmiştir. Sönmez ve Kaplan (2011) tarafından farklı tarımsal atıkların birlikte kompost yapıldığı bir çalışmada karanfil bitkilerinin kuru madde içerikleri ve makro besin içeriklerinde \% 100 tavuk gübresinin en iyi değerlerin elde edildiği uygulama olduğu belirlenmiştir.

Bu çalışma, tavuk gübresinin artan dozlarında yetiştirilen domates bitkisinin gelişimi, kalitesi, verimi ve besin içeriği üzerine etkileri ile bazı toprak verimlilik parametreleri üzerine olan etkilerinin belirlenmesi amacıyla yapılmıştır.

\section{Materyal ve Yöntem}

$\mathrm{Bu}$ araștırma Akdeniz Üniversitesi Ziraat Fakültesi'ne ait araştırma ve uygulama seralarında 2016 yılında yürütülmüştür. Sera koşullarında yürütülen çalışmada Çizelge 1'de özellikleri verilen toprağa tavuk gübresinin 3 farklı dozu $\left(0 \mathrm{~kg} \mathrm{da}^{-1}, 600\right.$ $\mathrm{kg} \mathrm{da}^{-1}, 1200 \mathrm{~kg} \mathrm{da}^{-1}$ ) uygulanmış ve tavuk gübresi dozlarının gelişme, verim ve kalite üzerine olan etkileri belirlenmeye çalışılmıştır. Deneme toprağı uzun yıllardır domates üretimi yapılan ve toprak özellikleri bakımından oldukça iyi özelliklere sahiptir. Deneme toprağının yıllardır yapılan gübre uygulamaları nedeniyle bitki besleme özellikleri yüksek olup deneme esnasında yapılan gübreleme programı bitkilerin beslenme düzeylerine göre düzenlenmiştir. Uygulama materyali olarak kullanılan tavuk gübresi ticari bir ürün olup, firma tarafından beyan edilen analiz sonuçları Çizelge 2'de verilmiştir.

Çizelge 1. Araştırmada kullanılan deneme toprağının bazı fiziksel ve kimyasal özellikleri.

Table 1. Some physical and chemical properties of soil used in study.

\begin{tabular}{|c|c|c|}
\hline Özellikler & Değer & Değerlendirme \\
\hline $\mathrm{pH}$ & 7.42 & Hafif alkalin \\
\hline Kireç (\%) & 17.20 & Çok fazla kireçli \\
\hline Bünye & - & Killi tın \\
\hline $\mathrm{EC}\left(\mathrm{dS} \mathrm{m}^{-1}\right)$ & 0.42 & Tuzsuz \\
\hline Organik Madde (\%) & 2.43 & $\mathrm{Az}$ \\
\hline Toplam azot (\%) & 0.15 & Çok iyi \\
\hline Alınabilir $\mathrm{P}_{2} \mathrm{O}_{5}\left(\mathrm{mg} \mathrm{kg}^{-1}\right)$ & 236.50 & Yüksek \\
\hline Değişebilir K (mg kg $\left.{ }^{-1}\right)$ & 568.20 & Yüksek \\
\hline Değişebilir $\mathrm{Mg}\left(\mathrm{mg} \mathrm{kg}^{-1}\right)$ & 469.80 & İyi \\
\hline Değiş̧ebilir Ca $\left(\mathrm{mg} \mathrm{kg}^{-1}\right)$ & 4259.00 & İyi \\
\hline Değişebilir $\mathrm{Na}\left(\mathrm{mg} \mathrm{kg}^{-1}\right)$ & 101.40 & Düşük \\
\hline Alınabilir Fe $\left(\mathrm{mg} \mathrm{kg}^{-1}\right)$ & 4.73 & İyi \\
\hline Alınabilir Mn ( $\left.\mathrm{mg} \mathrm{kg}^{-1}\right)$ & 10.70 & Yeterli \\
\hline Alınabilir $\mathrm{Zn}\left(\mathrm{mg} \mathrm{kg}^{-1}\right)$ & 9.24 & İyi \\
\hline Alınabilir $\mathrm{Cu}\left(\mathrm{mg} \mathrm{kg}^{-1}\right)$ & 6.80 & Yeterli \\
\hline
\end{tabular}

Çizelge 2. Kullanılan tavuk gübresinin bazı analiz özellikleri.

Table 2. Properties of poultry manure used in the study.

\begin{tabular}{lc}
\hline Özellikler & Değer \\
\hline Toplam organik madde, $(\%)$ & 55 \\
Toplam azot, $(\%)$ & 2 \\
Organik azot, $(\%)$ & 1 \\
Toplam $\mathrm{P}_{2} \mathrm{O}_{5},(\%)$ & 3 \\
Maksimum nem, $(\%)$ & 20 \\
pH & $6-8$ \\
\hline
\end{tabular}

Çalışmada bitki materyali olarak Tayfun $\mathrm{F}_{1}$ domates çeşidi kullanılmıştır. Deneme, tesadüf parselleri deneme desenine göre 3 tekerrürlü olarak planlanmış ve her parselde 12 bitki olacak şekilde 3 Şubat 2016 tarihinde dikilmiştir. Fideler sıra arası 40 $\mathrm{cm}$, sıra üzeri $90 \mathrm{~cm}$ olacak şekilde deneme parsellerine dikilmiş, dikimden sonraki bütün kültürel işlemler (sulama, ilaçlama vb.) tüm uygulama parsellerine eşit uygulanmıştır. Yetiştirme süresi boyunca bütün parsellere eşit $1.5 \mathrm{dS} \mathrm{m}^{-1}$ (20 $\mathrm{kg} \mathrm{da}^{-1} \mathrm{~N}, 15 \mathrm{~kg} \mathrm{da}^{-1} \mathrm{P}_{2} \mathrm{O}_{5}, 30 \mathrm{~kg} \mathrm{da}^{-1} \mathrm{~K}_{2} \mathrm{O}, 5 \mathrm{~kg} \mathrm{da}^{-1} \mathrm{CaO}, 2.5$ $\mathrm{kg} \mathrm{da}^{-1} \mathrm{MgO}$ ) olacak şekilde fertigasyon gübrelemesi yapılmış ve deneme 18 Haziran 2016 tarihinde sonlandırılmıştır. 
Denemede yaprak ve meyve örnekleri alınarak gerekli fiziksel ölçümler yapıldıktan sonra laboratuvara getirilmiş, yıkandıktan sonra $65^{\circ} \mathrm{C}$ 'de sabit ağırlığa gelinceye kadar kurutulduktan sonra öğütülerek analize hazır hale getirilmiştir (Kacar ve İnal 2008). Bitki analizleri için ise domates yaprak örneklerinde toplam $\mathrm{N}$ modifiye Kjeldahl yöntemine göre belirlenmiştir (Kacar ve İnal 2008). Ayrıca, P, K, Ca, Mg, Fe, $\mathrm{Mn}, \mathrm{Zn}$ ve $\mathrm{Cu}$ analizleri için bitki örnekleri Soltanpour ve Workman (1981) tarafından bildirildiği şekilde yaş yakılıp ICPOES cihazında okunmuştur.

Toprak örneklerinde pH (Jackson 1967), kireç $\left(\mathrm{CaCO}_{3}\right)$ (Evliya 1964), elektriksel iletkenlik (Anonim 1988), bünye (Bouyoucos 1955), organik madde (Black 1965), toplam N (Black 1957), alınabilir P (Olsen 1982), ekstrakte edilebilir K, $\mathrm{Ca}$ ve $\mathrm{Mg}$ (Kacar 1972) ve alınabilir $\mathrm{Fe}, \mathrm{Zn}, \mathrm{Cu}$ ve $\mathrm{Mn}$ analizleri (Lindsay ve Norwell 1978) yapılmıştır.

Domates meyvelerinde ortalama meyve çapı, bitki başına meyve sayısı, ortalama meyve ağırlığı, bitki başına verim değerleri tespit edilmiştir. Çalışmada ayrıca meyvelerin renk, suda çözünebilir kuru madde (SÇKM) miktarı, titre edilebilir asit (TEA) değeri, meyve suyu pH'sı ve C vitamini içeriği belirlenmiştir.

Domateslerde SÇKM miktarı belirlemek üzere meyve örnekleri katı meyve sıkacağından geçirilmiş ve meyve usaresi elde edilmiştir. Bu süzüntüden alınan örnek dijital refraktometre ile (Hanna HI96801, Hanna Istruments, USA) belirlenmiştir. Elde edilen sonuçlar \% olarak ifade edilmiştir. Örneklerde TEA miktarının belirlenmesi amaciyla $2 \mathrm{ml}$ meyve suyu, $0.1 \mathrm{~N}$ $\mathrm{NaOH}$ çözeltisi ile $\mathrm{pH}$ metrede (Inolab $\mathrm{pH}$ 720, WTW, Germany) $\mathrm{pH}=8.1$ 'e kadar titre edilmiştir. Sonuçlar \% sitrik asit cinsinden hesaplanmıştır (Demir 2002; Doğan ve ark. 2016). Meyvelerin kabuk renginde meydana gelen değişmeler meyvenin ekvator bölgesinden üç farklı noktadan Minolta CR400 (MINOLTA Camera Co, LTD Ramsey, NJ) marka renk ölçer ile CIE L*a*b* renk düzleminde belirlenmiştir (McGuire 1992; Doğan ve ark. 2017). Çalışmada meyve eti sertliği el penetromesi yardımıyla meyve ekvator bölgesinden üç farklı noktadan ölçülmüştür. Ölçümler 3 mm'lik bir çapa sahip uçla gerçekleştirilmiştir. Meyvelerin $\mathrm{C}$ vitamini içeriği Cemeroğlu ve ark. (2007) tarafından belirtilen metoda göre yapılmıştır. Bu amaçla meyveler \% 6'lık metafosforik asit çözeltisi ektrakte edilmiştir. Ekstraktan $5 \mathrm{ml}$ alınan örnek üzerine sırasıyla $5 \mathrm{ml}$ asetat tampon, $1 \mathrm{ml}$ 2,6-Diclorophenolindophenol ve $10 \mathrm{ml}$ ksilen eklenmiştir. Daha sonra tüpler $5000 \mathrm{rpm}$ 'de $4{ }^{\circ} \mathrm{C}$ sıcaklıkta 10 dakika süreyle santrifüj edilmiştir. Alınan üst faz spektrofotometre cihazında (Analytik Jena Specord 40,
Germany) $500 \mathrm{~nm}$ dalga boyunda okutulmuştur. Sonuçlar oluşturulan kalibrasyon eğrisi ile hesaplanmış ve mg $100 \mathrm{~g}^{-1}$ taze ağırlık olarak verilmiştir.

Laboratuvar analizleri ve ölçümler neticesinde elde edilen bulgular SPSS 17.0 paket programında varyans analizi yapılarak Duncan çoklu karşılaştırma testine tabi tutulmuştur (Yurtsever 1984).

\section{Bulgular ve Tartışma}

Farklı dozlarda tavuk gübresi uygulamalarının domates bitkisinde meyvede ortalama meyve çapı, ortalama meyve ağırlığı, bitki başı meyve sayısı, bitki başına verim, suda çözünür kuru madde (SÇKM), pH, renk, titre edilebilir asitlik, sertlik ve vitamin C içeriği üzerine olan etkileri Çizelge 3'te verilmiştir. Tavuk gübresi uygulama dozlarının, ortalama meyve çapı, ortalama meyve ağırlığı, SÇKM ve meyvelerde renk değerleri ( $\mathrm{L}, \mathrm{C}, \mathrm{H}$ değerleri) üzerine olan etkileri istatistiksel olarak önemli bulunmamış, ancak pH, bitki başı meyve sayısı, bitki başına verim, Vitamin $\mathrm{C}$ miktarı, titre edilebilir asitlik ve meyve sertlik değerleri istatistiksel olarak önemli bulunmuştur. Bitki başına meyve sayısı ve verim değerlerinde $600 \mathrm{~kg} \mathrm{da}^{-1}$ uygulaması en yüksek değerlerin elde edildiği uygulama olarak belirlenmiştir. Tavuk gübresi uygulamasıyla domates meyve veriminde artış sağlandığı bazı araştırmacılar tarafından bildirmiştir (Güler 2004; Mehdizadeh 2013). Ceyhan ve ark. (2000) domates yetiştiriciliğinde farklı organik gübre uygulamalarında en yüksek verim 6.3 ton $\mathrm{da}^{-1}$ ile dekara 5 ton uygulanan tavuk gübresinden elde edilmiştir.

Domates meyvelerinde titre edilebilir asitlik bakımından kontrol uygulaması en yüksek değeri sağlarken en düşük değerler tavuk gübresi dozlarında belirlenmiştir. Meyve sertliği bakımından ise $1200 \mathrm{~kg} \mathrm{da}^{-1}$ tavuk gübresi dozu en yüksek değerin elde edildiği uygulama olarak belirlenmiş, en düşük değerler kontrol ve $600 \mathrm{~kg} \mathrm{da}^{-1}$ dozlarından elde edilmiştir. Domates yetiştiriciliğinde organik gübrelerin kullanılmasıyla bazı kalite kriterlerinin (toplam kuru madde miktarı, $\mathrm{pH}$, antioksidan aktivitesi, sertlik değerleri, kül, protein ve azot miktarları, renk değerleri) kimyasal gübreleme ile yetiştirilenlere göre daha yüksek olduğu belirtilmiştir (Abdollah 2008).

Domates meyvelerinin besin içerikleri üzerine tavuk gübresi dozlarının etkisi $\mathrm{Ca}, \mathrm{Mn}$ ve $\mathrm{Cu}$ elementleri hariç diğer tüm besin elementlerinde istatistiksel olarak farklı düzeylerde önemli bulunmuştur (Çizelge 4). Artan tavuk gübresi dozları ile bitki besin içeriklerindeki artış paralel olmayıp $600 \mathrm{~kg} \mathrm{da}^{-1}$

Çizelge 3. Tavuk gübresi uygulamalarının domates meyvelerinin bazı kalite parametreleri üzerine etkileri ${ }^{1}$.

Table 3. The effects of poultry manure treatments on some tomato fruits quality parameters ${ }^{1}$.

\begin{tabular}{|c|c|c|c|c|}
\hline İncelenen Kriter & $0 \mathrm{~kg} \mathrm{da}^{-1}$ & $600 \mathrm{~kg} \mathrm{da}^{-1}$ & $1200 \mathrm{~kg} \mathrm{da}^{-1}$ & Önemlilik \\
\hline Ortalama meyve çapı (mm) & 62.14 & 64.07 & 62.74 & $1.515 \mathrm{öd}$ \\
\hline Ortalama meyve ağırlığ $1\left(g\right.$ meyve $\left.{ }^{-1}\right)$ & 115.83 & 118.17 & 111.00 & $1.330 \mathrm{öd}$ \\
\hline Bitki başı meyve sayısı (adet bitki ${ }^{-1}$ ) & $27.47 b^{2}$ & $32.70 \mathrm{a}$ & $28.07 \mathrm{~b}$ & $6.023 *$ \\
\hline Bitki başına verim (kg bitki $\left.{ }^{-1}\right)$ & $3.41 b^{2}$ & $3.91 \mathrm{a}$ & $3.43 b$ & $11.901 * *$ \\
\hline SÇKM (\%) & 5.07 & 4.83 & 4.90 & 0.4105 öd \\
\hline $\mathrm{pH}$ & 4.51 & 4.62 & 4.52 & 0.0529öd \\
\hline Lightness (L*) & 38.53 & 38.70 & 38.94 & 0.7912 öd \\
\hline Chroma $\left(\mathrm{C}^{*}\right)$ & 35.43 & 35.58 & 35.45 & 1.3192öd \\
\hline Hue angle $\left(\mathrm{H}^{\circ}\right)$ & 41.96 & 41.33 & 41.51 & 1.3544öd \\
\hline Titre edilebilir asitlik (\% sitrik asit) & $0.33 \mathrm{a}^{2}$ & $0.30 \mathrm{~b}$ & $0.30 \mathrm{~b}$ & $0.0231 *$ \\
\hline Meyve sertliği $\left(\mathrm{N} \mathrm{cm}^{-2}\right)$ & $8.58 b^{2}$ & $9.24 b$ & $10.85 \mathrm{a}$ & $1.4887 *$ \\
\hline $\mathrm{C}$ vitamini (mg $\left.100 \mathrm{~g}^{-1}\right)$ & $30.45 \mathrm{a}^{2}$ & $28.85 b$ & $28.99 b$ & $0.2917 *$ \\
\hline
\end{tabular}

${ }^{1}$ Değerler 3 tekerrür ortalamasıdır. ${ }^{2}$ Aynı harfle gösterilmeyen değerler arasındaki farklar $\% 5$ düzeyinde önemlidir. $*$ : $\mathrm{p}<0.05, * *$ : $\mathrm{p}<0.01$, öd: önemli değil. 
uygulaması bazı besin elementi içeriklerinde $1200 \mathrm{~kg} \mathrm{da}^{-1}$ uygulaması ile aynı sonucun elde edilmesini sağlamıştır. Meyvelerin K (\% 3.32) ve Fe (49.25 mg kg-1) içeriklerinde 1200 $\mathrm{kg} \mathrm{da}^{-1}$ uygulamas1 en yüksek değerlerin elde edilmesini sağlarken; $\mathrm{N}$ (\% 2.23), Mg (\% 0.16) ve $\left.\mathrm{Zn} \mathrm{(7.03} \mathrm{mg} \mathrm{kg}^{-1}\right)$ içeriklerinde hem $600 \mathrm{~kg} \mathrm{da}^{-1}$ hem de $1200 \mathrm{~kg} \mathrm{da}^{-1}$ uygulamaları en yüksek değerlerin elde edildiği grupta yer almışlardır. Önal ve ark. (2003) artan organik materyal ilavesinin domates meyvesinde besin konsantrasyonunda artışa neden olduğunu belirtmiştir. Çizelge 4'de yapılan değerlendirmede sadece P (\% 0.55) içeriklerinde en yüksek değer kontrolden elde edilmiş, kontrol uygulaması genel olarak en düşük değerlerin elde edildiği uygulama olarak belirlenmiştir.

Domates bitki örneklerinin besin içeriklerine farklı tavuk gübresi uygulamalarının etkileri bakımından yapılan değerlendirmede; $\mathrm{Ca}, \mathrm{Mg}$, $\mathrm{Zn}$ ve $\mathrm{Cu}$ içeriklerinde uygulamaların etkileri istatistiksel olarak önemli bulunmazken, diğer besin elementlerinin içerikleri üzerine tavuk gübresi uygulamalarının etkilerinin önemli olduğu belirlenmiştir (Çizelge 5). Bitki örneklerinin N (\% 3.56), P (\% 0.51) ve K (\% 3.44) içeriklerinde en yüksek değerler $1200 \mathrm{~kg} \mathrm{da}^{-1}$ uygulamasından elde edilirken, $\mathrm{Fe}\left(79.13 \mathrm{mg} \mathrm{kg}^{-1}\right.$ ve $\left.81.78 \mathrm{mg} \mathrm{kg}^{-1}\right)$ ve $\mathrm{Mn}\left(123.13 \mathrm{mg} \mathrm{kg}^{-1}\right.$ ve
$125.88 \mathrm{mg} \mathrm{kg}^{-1}$ ) içeriklerinde $600 \mathrm{~kg} \mathrm{da}^{-1}$ ve $1200 \mathrm{~kg} \mathrm{da}^{-1}$ tavuk gübresi uygulamaları en yüksek değerlerin elde edildiği uygulamalar olarak belirlenmişlerdir. Çalışmada kontrol uygulamaları en düşük değerlerin elde edildiği uygulama olarak belirlenmiştir (Çizelge 5). Topçuoğlu ve ark. (2001) örtü altı domates yetiştiriciliğinde toprağa uygulanan organik gübrelerin uygulama düzeylerine bağlı olarak bitkinin kuru madde miktarını, N, P, K ve Mg içeriğini artırdığını tespit etmiştir. Tavuk gübresinde bulunan organik azot miktarının yaklaşık $\%$ 90'inın ilk yıl mineralize olması bitki ve toprakta azot bakımından iyi sonuç alınmasının nedeni olarak belirtilmektedir (Smith ve Peterson 1982). Güler (2004) tavuk gübresinin açıkta domates yetiştiriciliğinde $600 \mathrm{~kg} \mathrm{da}^{-1}$ uygulanmasının verim, kalite ve bitki besin element içeriği açısından yeterli olduğunu bildirilmiştir. Ewulo ve ark. (2008) ve Adekiya ve Agbede (2009) tavuk gübresi uygulamalarının domates yapraklarının $\mathrm{N}$, $\mathrm{P}, \mathrm{K}, \mathrm{Ca}$ ve $\mathrm{Mg}$ içeriklerini artırdığını bildirmişlerdir.

Artan tavuk gübresi uygulamalarının deneme topraklarının $\mathrm{pH}$ düzeylerine olan etkileri istatistiksel olarak önemli bulunmazken, organik madde düzeyleri ve EC değerleri $\mathrm{p}<0.001$ düzeyde önemli bulunmuştur (Çizelge 6). Toprakların

Çizelge 4. Tavuk gübresi dozlarının domates meyvelerinin besin içerikleri üzerine etkileri ${ }^{1}$.

Table 4. The effects of poultry manure treatments on tomato fruits nutrient contents ${ }^{1}$.

\begin{tabular}{|c|c|c|c|c|}
\hline İncelenen Kriter \% & $0 \mathrm{~kg} \mathrm{da}^{-1}$ & $600 \mathrm{~kg} \mathrm{da}^{-1}$ & $1200 \mathrm{~kg} \mathrm{da}^{-1}$ & Önemlilik \\
\hline Azot (\%) & $1.95 \mathrm{~b}^{2}$ & $2.10 \mathrm{a}$ & $2.23 \mathrm{a}$ & $12.90 * *$ \\
\hline Fosfor (\%) & $0.55 \mathrm{a}^{2}$ & $0.52 b$ & $0.47 \mathrm{c}$ & $23.55 * * *$ \\
\hline Potasyum (\%) & $2.75 c^{2}$ & $2.95 \mathrm{~b}$ & $3.32 \mathrm{a}$ & $29.035 * * *$ \\
\hline Kalsiyum (\%) & 0.14 & 0.16 & 0.15 & 0.542 öd \\
\hline Magnezyum (\%) & $0.13 b^{2}$ & $0.16 \mathrm{a}$ & $0.15 \mathrm{a}$ & $6.50^{*}$ \\
\hline $\operatorname{Demir}\left(\mathrm{mg} \mathrm{kg}^{-1}\right)$ & $25.01 b^{2}$ & $28.16 b$ & $49.25 \mathrm{a}$ & $18.82 * *$ \\
\hline Çinko $\left(\mathrm{mg} \mathrm{kg}^{-1}\right)$ & $2.33 b^{2}$ & $5.45 \mathrm{a}$ & $7.03 \mathrm{a}$ & $14.13^{* *}$ \\
\hline Mangan $\left(\mathrm{mg} \mathrm{kg}^{-1}\right)$ & 12.08 & 12.09 & 12.34 & 0.22 öd \\
\hline Bakır $\left(\mathrm{mg} \mathrm{kg}^{-1}\right)$ & 7.79 & 18.44 & 36.86 & 2.32öd \\
\hline
\end{tabular}

Çizelge 5. Tavuk gübresi dozlarının domates yapraklarının besin içerikleri üzerine etkileri ${ }^{1}$.

Table 5. The effect of poultry manure treatments on tomato leaves nutrient contents ${ }^{1}$.

\begin{tabular}{|c|c|c|c|c|}
\hline İncelenen Kriter & $0 \mathrm{~kg} \mathrm{da}^{-1}$ & $600 \mathrm{~kg} \mathrm{da}^{-1}$ & $1200 \mathrm{~kg} \mathrm{da}^{-1}$ & Önemlilik \\
\hline Azot $(\%)$ & $2.85 b^{2}$ & $3.27 \mathrm{ab}$ & $3.56 \mathrm{a}$ & $5.35^{*}$ \\
\hline Fosfor $(\%)$ & $0.41 c^{2}$ & $0.47 \mathrm{~b}$ & $0.51 \mathrm{a}$ & $42.44 * * *$ \\
\hline Potasyum (\%) & $3.12 b^{2}$ & $3.18 \mathrm{~b}$ & $3.44 \mathrm{a}$ & $12.24 * *$ \\
\hline Kalsiyum (\%) & 4.86 & 4.90 & 5.07 & 0.412 öd \\
\hline Magnezyum (\%) & 0.48 & 0.45 & 0.49 & 1.563 öd \\
\hline $\operatorname{Demir}\left(\mathrm{mg} \mathrm{kg}^{-1}\right)$ & $71.04 b^{2}$ & $79.13 \mathrm{a}$ & $81.78 \mathrm{a}$ & $45.36 * * *$ \\
\hline Çinko $\left(\mathrm{mg} \mathrm{kg}^{-1}\right)$ & 12.41 & 12.89 & 13.05 & 0.787 öd \\
\hline Mangan $\left(\mathrm{mg} \mathrm{kg}^{-1}\right)$ & $109.62 b^{2}$ & $123.13 \mathrm{a}$ & $125.88 \mathrm{a}$ & $7.25^{*}$ \\
\hline Bakır (mg kg-1) & 10.51 & 10.60 & 10.06 & 0.387 öd \\
\hline
\end{tabular}

Çizelge 6. Tavuk gübresi uygulamalarının bazı toprak özellikleri üzerine etkileri ${ }^{1}$.

Table 6. The effects of poultry manure treatments on some soil parameters ${ }^{1}$.

\begin{tabular}{|c|c|c|c|c|}
\hline İncelenen Kriter & $0 \mathrm{~kg} \mathrm{da}^{-1}$ & $600 \mathrm{~kg} \mathrm{da}^{-1}$ & $1200 \mathrm{~kg} \mathrm{da}^{-1}$ & Önemlilik \\
\hline Organik Madde (\%) & $2.22 b^{2}$ & $3.00 \mathrm{a}^{2}$ & $3.10 \mathrm{a}^{2}$ & $27.38 * * *$ \\
\hline $\mathrm{pH}$ & 7.39 & 7.44 & 7.42 & 0.33 öd \\
\hline $\mathrm{EC}\left(\mathrm{dS} \mathrm{m}^{-1}\right)$ & $0.530 \mathrm{c}$ & $0.689 \mathrm{a}$ & $0.650 \mathrm{~b}$ & $139.72 * * *$ \\
\hline Azot $(\%)$ & $0.117 \mathrm{~b}$ & $0.177 \mathrm{a}$ & $0.203 a$ & $8.44 *$ \\
\hline Fosfor $\left(\mathrm{mg} \mathrm{kg}^{-1}\right)$ & $209.68 \mathrm{c}$ & $313.33 \mathrm{a}$ & $248.16 b$ & $160.82 * * *$ \\
\hline Potasyum ( $\left.\mathrm{mg} \mathrm{kg}^{-1}\right)$ & $724.77 \mathrm{c}$ & $969.33 \mathrm{a}$ & $875.33 b$ & $53.94 * * *$ \\
\hline Kalsiyum ( $\left.\mathrm{mg} \mathrm{kg}^{-1}\right)$ & 4549.33 & 4152.33 & 4319.67 & 2.58 öd \\
\hline Magnezyum (mg kg$\left.{ }^{-1}\right)$ & $452.20 \mathrm{~b}$ & $430.70 \mathrm{a}$ & $477.77 \mathrm{a}$ & $8.74 *$ \\
\hline $\operatorname{Demir}\left(\mathrm{mg} \mathrm{kg}^{-1}\right)$ & $2.66 \mathrm{~b}$ & $3.19 \mathrm{ab}$ & $3.92 \mathrm{a}$ & $5.90 *$ \\
\hline Çinko (mg kg$\left.{ }^{-1}\right)$ & $9.93 b$ & $9.90 \mathrm{~b}$ & $10.97 \mathrm{a}$ & $7.47 *$ \\
\hline Mangan $\left(\mathrm{mg} \mathrm{kg}^{-1}\right)$ & $16.88 \mathrm{a}$ & $10.80 \mathrm{~b}$ & $16.62 \mathrm{a}$ & $108.33^{* * *}$ \\
\hline Bakır ( $\left.\mathrm{mg} \mathrm{kg}^{-1}\right)$ & $5.94 \mathrm{~b}$ & $6.85 \mathrm{a}$ & $5.91 \mathrm{~b}$ & $12.54 * *$ \\
\hline
\end{tabular}


organik madde düzeyine $600 \mathrm{~kg} \mathrm{da}^{-1}$ ve $1200 \mathrm{~kg} \mathrm{da}^{-1}$ tavuk gübresi dozları (\% 3.00 ve $\% 3.10)$ aynı düzeyde etkide bulunmuştur. Toprak organik madde içeriği bakımından en düşük değer kontrol (\% 2.22) uygulamasından elde edilmiştir. Topraklara ilave edilen tavuk gübreleri ile toprak organik maddesi \% 35-40 oranında artış göstermiştir. Organik materyal ilaveleriyle toprak organik maddesinde artış gözlendiği birçok araştırmacı tarafından belirtilmektedir (Alagöz ve ark. 2006; Y1lmaz ve Alagöz 2010; Akalan 1987; Haynes ve Naidu 1998). Toprakların EC değerlerinde $600 \mathrm{~kg} \mathrm{da}^{-1}$ uygulaması $(0.689$ $\mathrm{dS} \mathrm{m}^{-1}$ ) en yüksek değerin elde edildiği uygulama olurken en düşük değer kontrolden $\left(0.530 \mathrm{dS} \mathrm{m}^{-1}\right)$ elde edilmiştir. Organik gübre ilavesi ile toprakların tuzluluğu artmasına rağmen bu artış toprak tuzluluğunu tehdit edecek düzeylere ulaşmamıştır. Soil Survey Staff (1951) tarafindan yapılan sinıflandırmaya göre toprak örneklerinin tuzsuz sınıfına girdikleri belirlenmiştir.

Toprakların besin konsantrasyonlarında ise $\mathrm{Ca}$ hariç tüm elementler üzerine tavuk gübresi uygulamalarının etkileri istatistiksel olarak önemli bulunmuştur. Tavuk gübresinin 600 $\mathrm{kg} \mathrm{da}^{-1}$ ve $1200 \mathrm{~kg} \mathrm{da}^{-1}$ dozları toprakların $\mathrm{N}(\% 0.177$ ve $\% 0.203)$ ve $\mathrm{Mg}$ (430.70 $\mathrm{mg} \mathrm{kg}^{-1}$ ve $\left.477.77 \mathrm{mg} \mathrm{kg}^{-1}\right)$ konsantrasyonlarında aynı düzeyde etkide bulunurken; $\mathrm{P}$ (313.33 $\left.\mathrm{mg} \mathrm{kg}^{-1}\right), \mathrm{K}\left(969.33 \mathrm{mg} \mathrm{kg}^{-1}\right)$ ve $\mathrm{Cu}\left(6.85 \mathrm{mg} \mathrm{kg}^{-1}\right)$ konsantrasyonlarında $600 \mathrm{~kg} \mathrm{da}^{-1}$ uygulamas1, Fe (3.92 $\left.\mathrm{mg} \mathrm{kg}^{-1}\right)$ ve $\mathrm{Zn}\left(10.97 \mathrm{mg} \mathrm{kg}^{-1}\right)$ konsantrasyonlarında da $1200 \mathrm{~kg} \mathrm{da}^{-1}$ uygulaması en yüksek değerlerin elde edildiği uygulamalar olarak belirlenmiştir. Mn konsantrasyonunda ise kontrol (16.88 $\left.\mathrm{mg} \mathrm{kg}^{-1}\right)$ ile $1200 \mathrm{~kg} \mathrm{da}^{-1} \quad\left(16.62 \mathrm{mg} \mathrm{kg}^{-1}\right)$ tavuk gübresi uygulaması en yüksek değerlere sahipken en düşük değer 600 $\mathrm{kg} \mathrm{da}^{-1}\left(10.80 \mathrm{mg} \mathrm{kg}^{-1}\right)$ dozundan saptanmıştır. Ca ve Mn hariç tüm elementlerde en düşük değerler kontrolden elde edilmiştir. Kacar ve Katkat (2007), toprakların fosfor içerikleri üzerine toprak organik maddesinin etkisinin yüksek olduğunu bildirmiştir. Duyar (2007) tavuk gübresi uygulaması ile marul bitkisinde önemli oranda azot artışı sağlamıştır. Kaplan ve ark. (2006) kan unu ve tavuk gübresi uygulamalarının sonbahar döneminden ilkbahar dönemine doğru toprağın $\mathrm{pH}$, EC ve $\mathrm{K}$ içeriğinde azalmaya, $\mathrm{N}, \mathrm{P}, \mathrm{Ca}, \mathrm{Mg}, \mathrm{Fe}$ ve $\mathrm{Mn}$ içeriğinde ise artışa neden olduğunu bildirmişlerdir. Güneş (2007) organik uygulamaların (leonardit) toprakların makro element içeriklerinde artş̧a neden olduğunu bildirmiştir. Morlat ve Chaussod (2008) organik uygulamalarla toprakların potasyum içeriklerinin arttığını bildirmektedir. Şahin (2013) tavuk gübresinin zeytin yetiştirilen toprakların değişebilir demir ve bakır içeriğinde olumlu etkilerinin olduğunu belirlemiştir. Adekiya ve Ojeniyi (2002) tavuk gübresinin toprakların fiziksel özelliklerini iyileştirdiğini ve besin elementlerinin alınabilirliğini artırdığını bildirmiştir. Steiner ve ark. (2007) artan dozlardaki tavuk gübresi uygulamasının toprak $\mathrm{pH}$ 's1, fosfor, kalsiyum ve magnezyum kapsamında artışa neden olduğunu bildirmişlerdir.

\section{Sonuç}

Tarımsal üretimde verimliliği artıran en önemli unsurlardan birisi olan gübreleme uygulamalarında organik gübreleme; hem toprak özellikleri üzerine olan önemli etkileri nedeniyle hem de bitki gelişimine katkı sağlaması nedeniyle son yıllarda çok fazla oranda tercih edilmektedir. Özellikle kimyasal gübrelerin etkinliğinin artırılması nedeniyle verimde ciddi artışlar sağladığı bilinmektedir. Tavuk gübreleri son yıllarda tavukçuluk sektöründeki artışla birlikte tarım sektöründe kaliteli ürün temini bakımından öne çıkmaktadır. İşlenmiş tavuk gübrelerinin toprak özellikleri ve bitki gelişimindeki önemli katkıları yanında ithal ürünlere göre ekonomik olarak daha uygun olması nedeniyle kullanımları her geçen gün daha da artmaktadır. Bu çalışmada da tavuk gübresinin farklı dozlarının domates bitkisinde gelişme, verim, kalite ve toprak özelliklerindeki değişimler gözlenmeye çalışılmıştır. Tavuk gübresinin özellikle meyvedeki verim analizlerinde $600 \mathrm{~kg} \mathrm{da}^{-1}$ uygulaması önerilirken meyvedeki besin elementi içeriklerinde $1200 \mathrm{~kg} \mathrm{da}^{-1}$ uygulaması en iyi sonuçları sağlamıştır. Bitki besin içeriklerinde $1200 \mathrm{~kg} \mathrm{da}^{-1}$ uygulaması, toprakta makro besin içeriklerinde $600 \mathrm{~kg} \mathrm{da}^{-1}$ uygulaması ve mikro besin içeriklerinde de 1200 $\mathrm{kg} \mathrm{da}^{-1}$ uygulaması en yüksek değerlerin elde edildiğ uygulamalar olarak belirlenmiştir. Kimyasal gübre uygulamasına ilave olarak uygulanan tavuk gübresi dozlarının özellikle verim unsurlarında artışa neden olması topraktaki besin elementlerinin yarayışlılığının artırılmasından kaynaklandığı düşünülmektedir. Özellikle $600 \quad \mathrm{~kg} \mathrm{da}^{-1}$ uygulamasının ekonomik doz olarak ortaya çıkmasının uzun süreli çalı̧̧malarla desteklenmesi gerekliliği de dikkate alınması gereken bir durumdur. Toprak özelliklerinin iyileştirilmesi ve besin elementlerinin alınabilirliğinin artırılmasında organik gübrelerin olumlu etkilerinden dolayı kullanımlarının artırılması desteklenmelidir. Özellikle toprak organik maddesinin düşük olduğu alanlarda bu uygulamalar yıllar boyunca tekrarlanarak toprak kalitesinde ve sürdürülebilir üretimde artışlar sağlanabilir.

\section{Kaynaklar}

Abdollah F (2008) Organik ve konvansiyonel domates ürünlerinin ayırt edilme yöntemleri ve kalite farklarının incelenmesi. Doktora Tezi, Ege Üniversitesi Fen Bilimleri Enstitüsü, İzmir.

Adekiya AO, Ojeniyi SO (2002) Evaluation of tomato growth and soil properties under methods of seedling bed preparation in an alfisol in the rainforest zone of southwest Nigeria. Soil and Tillage Res. 64: $275-279$.

Adekiya AO, Agbede TM (2009) Growth and yield of tomato (Lycopersicon Esculentum Mill) as influenced by poultry manure and NPK fertilizer. Emirates Journal of Food and Agriculture 21(1): 10-20.

Akalan İ (1987) Toprak Bilgisi. Ankara Üniversitesi Ziraat Fakültesi Yayınları: 1025, Ankara, s. 309.

Alagöz Z, Yılmaz E, Öktüren F (2006) Organik materyal ilavesinin bazı fiziksel ve kimyasal toprak özellikleri üzerine etkileri. Akdeniz Üniversitesi Ziraat Fakültesi Dergisi 19(2): 245-254.

Anonim (1988) Meyve, sebze ve mamulleri-nitrit ve nitrat tayinimoleküler absorpsiyon spektrofotometrik metot. Türk Standardı, ICS 67.080, TS 6183/Aralık 1988.

Bellitürk K (2016) Sürdürülebilir Tarımsal Üretimde Katı Atık Yönetimi İçin Vermikompost Teknolojisi. Çukurova Tarım ve Gıda Bil. Dergisi 31(3): 1-5, Adana.

Bender D, Erdal İ, Dengiz O, Gürbüz M ve Tarakçığlu C (1998) Farklı Organik Materyallerin Killi Bir Toprağın Bazı Fiziksel Özellikleri Üzerine Etkileri. International Symposium On Arid Region Soil. International Agrohydrology Research And Training Center, Menemen, İzmir, s. 506-510.

Black CA (1957) Soil-plant relationships. John Wiley and Sons, Inc., New York.

Black CA (1965) Methods of Soil Analysis Part 2, Amer. Society of Agronomy Inc., Publisher Madisson, Wilconsin, U.S.A., pp. 13721376.

Bouyoucos GJ (1955) A recalibration of the hydrometer method for making mechanical analysis of the soils. Agronomy Journal 4(9): 434. 
Brohi AR, Karaman MR, Aktaş A (1995) Residual effect of some organic fertilizers on dry matter yield and NP content of maize crop grown on a calcareous and non-calcareous soil. Soil Fertility and Fertilizer Managemen 9th International Symposium of CIEC, 25-30 Sept. 1995, Kuşadası, Turkey.

Cemeroğlu B, Yemencioğlu A ve Özhan M (2007) Gıda analizleri kitabı. Bizim Grup Basımevi, s. 45-84, Ankara.

Ceyhan Ş, Yoldaş F, Mordoğan N, Çakııı H (2000) Domates yetiştiriciliğinde farklı hayvansal gübrelerin verim ve kaliteye etkisi. II. Sebze Tarımı Sempozyumu, 11- 13 Eylül, Isparta, s. 5155.

Demir H (2002) Bazı sebze türlerinin organik tarım yöntemleri ile yetiştirilmesi, verim ve kalite analizlerinin yapılması üzerine bir araştırma. Yüksek Lisans Tezi. Akdeniz Üniversitesi Fen Bilimleri Enstitüsü, Antalya.

Doğan A, Selcuk N, Erkan M (2016) Comparison of pesticide-free and conventional production systems onpostharvest quality and nutritional parameters of peppers in differentstorage conditions. Scientia Horticulturae 207: 104-116.

Doğan A, Kurubaş MS, Erkan M (2017) Farklı dozlarda 1Metilsiklopropen (1-MCP) uygulamalarının 'Hass' avokado çeşidinin depolanması üzerine etkileri. Mediterranean Agricultural Sciences 30(2): 71-78.

Duyar H (2007) Yeşil gübrelemenin serada organik sebze üretimine etkileri. Doktora Tezi, Ege Üniversitesi Fen Bilimleri Enstitüsü, İzmir.

Evliya H (1964) Kültür bitkilerinin beslenmesi. Ankara Üniversitesi Ziraat Fakültesi Yayınları, Sayı: 10, Ankara.

Ewulo BS, Ojeniyi SO, Akanni DA (2008) Effect of poultry manure on selected soil physical and chemical properties, growth, yield and nutrient status of tomato. African Journal of Agricultural Research 3(9): 612-616.

Gamliel A, Stapleton JJ (1993) Effect of chicken compost or ammonium phosphate and solarization on pathogen control, rizosphere microorganisms, and lettuce growth. Plant Disease 77(9): 886-891.

Güler S (2004) Tavuk gübresi ve inorganik gübre uygulamasının domateste verim, kalite ve yaprağın besin element içeriği üzerine etkileri. Derim 21(1): 21-29.

Güneş A (2007) Alüviyal materyaller üzerinde oluşan topraklarda yetiştirilen mısır bitkisinin verim ve besin içeriği üzerine organik ve mineral gübre uygulamalarının etkisi. Yüksek Lisans Tezi, Atatürk Üniversitesi Fen Bilimleri Enstitüsü, Erzurum.

Haynes RJ, Naidu R (1998) Influence of lime, fertilizer and manure application on soil organic matter content and soil physical conditions: A review. Nutrient Cycling in Agroecosystem 51: 123137.

Jackson ML (1967) Soil chemical analysis. Prentice Hall of India Private Limited, New Delhi.

Kacar B (1972) Bitki ve toprağın kimyasal analizleri. II. Bitki Analizleri, A.Ü. Ziraat Fak. Yayınları: 453, Ankara.

Kacar B, Katkat V (2007) Bitki besleme. Nobel Yayınları, ISBN: 9789515918345.

Kacar B, İnal A (2008) Bitki analizleri. Nobel Yayınları, s. 1241.

Kaplan M, Sönmez S, Polat E, Demir H ve Sönmez İ (2006) Kan unu ve tavuk gübresi uygulamalarının toprak özellikleri üzerine etkisi, Türkiye III. Organik Tarım Sempozyumu, 1-4 Kasım, Yalova, s. 533-541.

Kocabaş I, Sönmez İ, Kalkan H, Kaplan M (2007) The effects of different organic manure applications on essential oil ratio and nutrient contents of sage (Salvia fructicosa Mill.) Akdeniz Univ. Journal of the Faculty of Agriculture 20(1): 105-110.

Lindsay WL, Norvell WA (1978) Development of a DTPA soil test for Zinc, Iron, Manganese and Copper. Soil Science Society of
America Journal 42(3): 421-428. Madisson, Wilconsin, USA, 13721376.

Masarirambi MT, Hlawe MM, Oseni OT, Sibiya TE (2010) Effects of organic fertilizers on growth, yield, quality and sensory evaluation of red lettuce (Lactuca sativa L.) 'VenezaRoxa'. Agriculture and Biology Journal of North America 1(6): 1319-1324.

McGuire RG (1992) Reporting of objective colour measurements. HortScience 27: 12541255.

Mehdizadeh M, Darbandi EI, Naseri-Rad H, Tobeh A (2013) Growth and yield of tomato (Lycopersicon esculentum Mill.)as influenced by different organic fertilizers. International Journal of Agronomy and Plant Production 4(4): 734-738.

Moreira MA, Dos Santos CAP, Lucas AAT, Bianchini FG, De Souza IM, Viegas PRA (2014) Lettuce production according to different sources of organic matter and soil cover. Agricultural Sciences 5: 99-105.

Morlat R, Chaussod R (2008) Long-term additions of organic amendments in a loire valley vineyard. I. Effects on Properties of a Calcareous Sandy Soil. American Journal of Enology\& Viticulture 59(4): 353-363.

Ogbadu GH, Easmon J (1989) Influence of inorganic and organic fertilizers on the chemical composition of three Department of Biochemistry, eggplant cultivars. Ahmadu Bello University, Zaira, Nigeria.

Olsen SR, Sommers EL (1982) Phosporus soluble in sodium bicarbonate, methods of soil analysis, part 2, Chemical and Microbiological Properties. Edit: A.L. Page, P.H. Miller, D.R. Keeney, 404-430.

Önal MK, Topçuoğlu B, Arı N (2003) Toprağa uygulanan kentsel arıtma çamurunun domates bitkisine etkisi* 2 . gelişme ve meyve özellikleri ile meyvede mineral içerikleri. Akdeniz Üniversitesi Ziraat Fakültesi Dergisi 16(1): 97-106.

Rynk R (1992) On farm composting handbook (NRAES-54) Northeast Regional Agricultural Engineering Service. Ithaca, New York. pp. 186.

Shirani H, Hajabbasi MA, Afyuni M and Hemmat A (2002) Effects of farmyard manure and tillage systems on soil physical properties and corn yield in central Iran. Soil and Tillage Research 68: 101-108.

Smith JH and Peterson JR (1982) Recycling of nitrogen through land application of agricultural, food, processing, and municipal wastes. In: Nitrogen in Agricultural Soils (Ed. F. J. Stevenson), 791-831.

Soil Survey Staff (1951) Soil survey manuel. Agricultural Research Administration, U.S Depth. Agriculture, Handbook No: 18, pp. 340-377.

Soltanpour PN, Workman SM (1981) Use of inductively-coupled plasma spectroscopy for the simultaneous determination of macro and micro nutrients in $\mathrm{NH}_{4} \mathrm{HCO}_{3}$-DTPA extracts of soils. In Barnes R.M. (ed). Developments in Atomic Plasma Analysis, USA, pp. 673-680.

Sönmez I, Kaplan M (2011) The Effects of Some Agricultural Wastes Composts on Carnation Cultivation. African Journal of Agricultural Research 6(16): 3936-3942.

Steiner C, Teixeria WG, Lehmann J, Nehls T, De Macedo JLV, Blum WEH, Zech W (2007) Long term effects of manure, charcoal and mineral fertilization on crop production and fertility on a highly weathered Central Amazonian upland soil. Plant and Soil 291(12): 275-290.

Şahin G. (2013) Organik Zeytin Yetiştiriciliğinde Farklı Gübre Dozlarının Toprak Özellikleri, Yaprak Besin Elementi içeriği ve Yağ kalitesi Üzerine Etkileri. Yüksek Lisans Tezi, Adnan Menderes Üniversitesi, Fen Bilimleri Enstitüsü, Aydın.

Tavalı İE, Uz İ, Orman Ş (2014) Vermikompost ve tavuk gübresinin yazlık kabağın (Cucurbita pepo L. cv. Sakız) verim ve kalitesi ile toprağın bazı kimyasal özellikleri üzerine etkileri. Akdeniz Üniversitesi Ziraat Fakültesi Dergisi 27(2): 119-124. 
Topçuoğlu B, Önal MK, Arı N (2001) Toprağa kentsel katı atık kompostu ve kentsel atıksu arıtma çamuru uygulamalarının sera domatesinde kuru madde miktarı ve bazı bitki besin içerikleri üzerine etkisi. GAP II. Tarım Kongresi, 24- 26 Ekim, Şanlıurfa.

Yılmaz E, Alagöz Z (2010) Effects of short-term amendments of farmyard manure on some soil properties in the Mediterranean Region-Turkey, Journal of Food Agriculture\&Environment 8: 859862 .
Yurtsever N (1984) Deneysel istatistik metotları. Köy Hizmetleri Genel Müdürlüğü Yayınları, No: 56, Ankara. 